\title{
Experiential Learning for All
}

\author{
Libby V. Morris ${ }^{1}$
}

Published online: 2 February 2016

(C) Springer Science+Business Media New York 2016

The University of Georgia (UGA) has a long and deep commitment to the education of undergraduate students, flowing from the original charter of 1785 which called the youth "... the rising hope of our Land...". Today more than 27,000 undergraduates study the liberal arts, sciences, social sciences, and professional education programs across 16 colleges and schools. These mostly 18-22 year-old students enroll in a complex network of more than 6,000 courses comprising 25 baccalaureate degrees in 140 fields. Beyond the traditional major and minor, additional learning opportunities are created by more than 600 organizations in student affairs, by internships and interdisciplinary activities, by study abroad trips, and by undergraduate research. Somewhere I saw the term "menu-driven sprawl," phrasing which may capture the challenge of living and learning in a large university.

At large research universities, we struggle to make "sense" of the undergraduate experience. What are students learning in addition to disciplinary knowledge? Where do they learn those things? How do the curricular and co-curricular elements overlap to meet the sometimes poorly understood goals of general education? In 2014, recognizing UGA's extensive involvement in learning beyond the classroom, a faculty committee began to explore "what an experiential learning program might look like." The fact that UGA students and faculty already have extensive involvement in service learning, study abroad, undergraduate research, internships, and other educational activities that are hands-on and outside of the traditional class made the conversation lively and productive. In the end, the University Council adopted a requirement that all undergraduate students must have at least one high-quality, hands-on learning experience prior to graduation.

A brief overview of UGA's current involvement in learning beyond the classroom shows our potential to take a program of experiential learning to an even higher level. For example, by working with faculty members and students the Office of Service Learning has built a robust program of more than 200 service-learning courses which enrolled over 8,100 students in 2014-15 alone. Those students reported approximately 276,000 hours of service, valued at more than $\$ 6.4$ million in volunteer time. (See http://servicelearning.uga.edu/service-learningby-the-numbers/)

Libby V. Morris

1vmorris@uga.edu 
International education presently oversees more than 100 faculty-led study abroad programs to more than 50 countries and to UGA's three residential centers located in Cortona (Italy), San Luis (Costa Rica), and Oxford (England). In 2014-15 approximately 2,500 students studied internationally for academic credit, and UGA ranked $11^{\text {th }}$ on the Institute of International Education's 2015 Open Doors report. (See http://oie.uga.edu/docs/general/201415-OIE-Annual-Global-Engagement-Report.pdf/) In 2014-15, the Center for Undergraduate Research Opportunities matched 488 students with 302 faculty members to work side-by-side in research. (See https://curo.uga.edu/about/) These are only a few of the examples of learning beyond the classroom at UGA.

The incoming class of first-year students in fall 2016 will be the first required to participate in a hands-on experiential learning activity, making UGA one of a "growing number of large universities who [sic] are embracing experiential learning to enhance their students' education" (Berner 2015). Programs and units all across campus have been carefully revising activities and crafting new proposals for faculty review to become part of the program for experiential learning. I am pleased to see UGA give dedicated attention to experiential learning, which to-date has largely been a ground-up activity pursued by students and enabled by faculty members. If participation in "multiple experiences" is an indicator of success, then we have met with high achievement thus far. We must attend to shifts, however, from voluntary to "required" and the potential to effect enthusiasm. How will the \$1 million dollar endowment for experiential learning raise the bar? The research on experiential learning suggests that high-impact, out-ofclass experiences can be transformative; they can help students integrate academic knowledge and real world learning; they can support a more seamless transition from college to a career; they may enhance the development of more engaged citizens.

After completing the painstaking effort of laying the foundation for a program, I hope we will soon progress to asking key questions about student learning and program effectiveness. What difference does a required hands-on experience make in student learning? What are the skills, abilities, and competencies that we expect students to gain from our experiential learning programs? How will we communicate those desired outcomes to students, partners, and the academic community? In curricular matters, I think we too often "let the thing speak for itself." With this innovative initiative we need to state clearly what we hope to accomplish, and we should design assessments to see if integrative learning occurred.

I offer a tip of the hat to those faculty members and staff who work tirelessly to improve the student learning experience for all—both inside and outside of the classroom, not only at our institution but throughout higher education.

\section{References}

Berner, M. (2015, May 15). Colleges strive to meet demand for a more hands-on education. The Chronicle of Higher Education. Retrieved from chronicle.com/article/Colleges-Strive-to-Meet-Demand/230189 